\title{
MR T2* Evaluation of the Hepatic and Myocardial Iron Deposition in Thalasemia Major Patients and the Correlation of the Results with Serum Ferritin Levels and Cardiac Functions
}

\author{
Talasemi Major Hastalarında Kardiyak ve Karaciğer \\ Demir Birikiminin T2* Manyetik Rezonans Görüntüleme \\ ile Değerlendirilmesi ve Sonuçların Serum Ferritin \\ Değerleri ve Kardiyak Fonksiyonlar ile Korelasyonu
}

Dilek Öncel $\odot$ Aysun Çakır $\odot$ Güray Öncel $\odot$

\begin{abstract}
Objective: In this study we aimed to evaluate the correlation between myocardial iron deposition and cardiac functions along with the correlations between myocardial iron deposition, hepatic iron deposition and serum ferritin levels in beta thalasemia major patients.

Method: A total of 145 patients diagnosed with beta thalasemia major $(85$ males and 60 females aged between 9-53 years), and applied to our hospital between March 2016 and September 2018 were retrospectively evaluated. $T 2^{*}$ calculations were done for the heart and the liver. As for cardiac functions left ventricular ejection fraction and wall motion were evaluated. Serum ferritin levels between $20-250 \mathrm{ng} / \mathrm{m} /$ were accepted as normal. The correlations between myocardial iron deposition and cardiac functions as well as between myocardial, hepatic iron deposition and serum ferritin levels were statistically evaluated.

Results: The statistical analysis revealed a significant correlation between cardiac functional abnormalities and the severity of myocardial iron deposition. A statistically significant correlation was also found between myocardial iron deposition and serum ferritin levels in regard of both its presence and grades of severity. Similarly, hepatic iron deposition and serum ferritin levels were found to be correlated. On the other hand, no significant correlation was detected between hepatic and myocardial iron accumulations. Conclusion: MRI is an accurate tool to quantatively evaluate hepatic and myocardial iron deposition in thalasemia major patients. The periodical follow up of patients with MRI examinations for hepatic and cardiac iron deposition in addition to serum ferritin levels may help to prevent organ dysfunction by modifying the treatment in patients with thalassemia major and other transfusion-dependent patients.
\end{abstract}

Keywords: Iron overload, myocardial iron, hepatic iron, magnetic resonance imaging, thalasemia major Öz

Amaç: Bu çalışmada, transfüzyon bağımlı beta-talasemi major hastalarında myokardiyal demir birikimi ile kardiyak fonksiyonlar arasındaki ilişkiyi, myokardiyal demir birikimi ile karaciğer demir birikimi arasındaki ilişkiyi, myokardiyal ve karaciğer demir birikimi ile serum ferritin seviyesi arasındaki ilişkiyi değerlendirmeyi amaçladık.

Yöntem: Çalışmada beta-talasemi major tanısı bulunan ve hastanemize Mart 2016-Eylül 2018 tarihleri arasında başvuran 145 hasta (85 erkek, 60 kadın, 9-53 yaşları arasında) retrospektif olarak incelendi. Kalp ve karaciğerden $T 2 *$ ölçümleri yapıldı. Kalp fonksiyonları açısından sol ventrikül ejeksiyon fraksiyonu ve duvar hareketleri değerlendirildi. Serum ferritin değerleri için 20-250 ng/ml aralığı normal sınırlarda kabul edildi. Myokardiyal demir birikimi ile kardiyak fonksiyonlar arasındaki ilişki ile myokardiyal ve karaciğer demir birikimi ile serum ferritin seviyesi arasındaki ilişkiler istatistiksel açıdan değerlendirildi.

Bulgular: istatistiksel analizler sonucunda kalpte demir birikiminin varlığının kardiyak fonksiyonları bozduğu ve birikimin artmasının fonksiyon bozukluğu ile korelasyon gösterdiği saptandı. Aynı zamanda myokardiyal demir birikimi ile serum ferritin değerleri arasında hem demir birikiminin varlığı, hem de şiddeti açısından anlamlı korelasyon saptandı. Benzer şekilde karaciğer demir birikimi ile serum ferritin değerleri arasında da anlamlı korelasyon gösterildi. Öte yandan karaciğer demir birikimi ile kardiyak demir birikimi arasında anlamlı korelasyon saptanmadı.

Sonuç: Sonuç olarak, MRG görüntüleme beta-talasemi major hastalarında karaciğer ve myokardiyal demir birikimini göstermede etkili bir yöntemdir. Hastaların serum ferritin ölçümlerine ek olarak MRG ile karaciğer ve myokardiyal demir birikimine yönelik olarak düzenli takip edilmesi talasemi major ve transfüzyona bağımlı diğer hastalarda tedavi sürecini șekillendirerek uygun șelasyon tedavisi ile organ disfonksiyonunu engellemeye yardımcı olabilir.

Anahtar kelimeler: Demir birikimi, kardiyak demir birikimi, karaciğer demir birikimi, manyetik rezonans görüntüleme, talasemi major
Received/Geliş: 03.12.2019

Accepted/Kabul: 10.05.2020

Published Online: 22.12.2020

Dilek Öncel

SBÜ İzmir Tepecik Eğitim ve Araştırma Hastanesi,

İzmir - Türkiye

dilekoncel@hotmail.com ORCiD: 0000-0001-5341-5558

A. Çakır 0000-0001-9047-4960 Sirnak Devlet Hastanesi, Şırnak, Türkiye

G. Öncel 0000-0001-9674-6197 Çiğli Bölge Eğitim Hastanesi, Izmir, Türkiye 


\section{INTRODUCTION}

Beta thalasemia is an inherited hemolytic anemia caused by ineffective hematopoesis due to impaired synthesis of $\beta$-chains of hemoglobin resulting from point mutations in the $\beta$-globin gene ${ }^{(1)}$. Thalasemia is particularly prevalent in Mediterranean countries including Turkey ${ }^{(2,3)}$.

The conventional therapy of beta thalasemia major is periodical blood transfusions which may cause iron accumulation in many organs including bone marrow, liver, spleen, pancreas, hypophysis and heart, despite chelation therapy ${ }^{(1,4)}$. The reason of this iron overload is extravascular hemolysis associated with chronic administration of blood and increased intestinal absorption of iron ${ }^{(4-6)}$. Iron accumulation has toxic effects and may cause functional impairment in the effected organs ${ }^{(4,5)}$. For instance in liver, it may cause cirrhosis and hepatocellular carcinoma and cardiac iron overload may cause progressive cardiomyopathy leading to arrhythmia, cardiac failure and sudden cardiac death ${ }^{(4-6)}$. Nevertheless, the major cause of mortality in thalasemia, like other transfusion-dependent anemia patients, is heart failure resulting from myocardial iron accumulation ${ }^{(6-8)}$.

Therefore, early detection of the presence and extent of iron accumulation in these patients is crucial ${ }^{(4-6,9)}$. Indirect serum markers used in the followup of iron overloading, such as measurements of serum ferritin may be inadequate and have a restricted predictive value to evaluate the disease process ${ }^{(9-11)}$. Also, being an acute phase reactant, serum ferritin levels may be elevated in different clinical conditions like infections, inflammatory processes, liver failure or malignant diseases ${ }^{(12)}$.

On the other hand, magnetic resonance imaging (MRI) can provide a direct, noninvasive method to monitor iron deposition in tissues using the paramagnetic characteristics of iron with the $\mathrm{T} 2$ and $\mathrm{T} 2$ * relaxation parameters ${ }^{(6,13-15)}$. Resulting from the increase of magnetic field heterogeneity, the iron deposits cause shortened $\mathrm{T} 2$ or $\mathrm{T} 2 *$ relaxation times and this shortening is proportional to the iron content $(6,13)$. This technique is simple, reproducible and transferable. It can quantify tissue iron rapidly and effec- tively which makes $M R$ a potential standard and noninvasive technique to monitor iron deposition $(6,13-17)$.

In our study, we used MRI for quantification and grading of the hepatic and myocardial iron accumulation and determined serum ferritin levels of patients with thalasemia. The purpose of our study was to evaluate the relationship between the myocardial iron deposition and cardiac functions, and to assess the correlations between myocardial iron deposition, hepatic iron accumulation and serum ferritin levels.

\section{MATERIALS and METHODS}

Institutional Review Board approved our study and we obtained informed consent from all patients or guardians.

We included 145 beta thalasemia major patients (aged between 9-53 years; mean age: 24, 85 males and 60 females) who were admitted to our hospital between March 2016 and September 2018 and had undergone MR examinations. All of the patients have been on follow up in hematology clinic with the diagnosis of beta thalasemia and were having periodical blood transfusions to keep the hemoglobin level of at least at $8 \mathrm{~g} / \mathrm{dL}$. Also all patients were on iron chelation therapy for a minimum of 18 months.

MR examinations were performed for quantifying hepatic and cardiac iron deposition and assessing left ventricular function. Along with MR examinations, serum ferritin levels were being studied on regular basis. Serum ferritin levels were monitored by ELISA using a pretransfusion samples. All of the test results and MR reports were available on the archiving system of the hospital (PACS).

The patients with known chronic hepatic diseases (both congenital or acquired), and the patients whose serum ferritin levels or MR examinations were not available were excluded from the study group. We also excluded the patients whose MR examinations were artifactous (due to technical or personal reasons) and calculations were not reliable,. The total number of 27 patients were excluded from the study and in the remaining 145 patients, we ret- 
rospectively evaluated MR examinations along with the test results.

Therefore, the following parameters were analyzed in the study: (a) serum ferritin, (b) hepatic and myocardial $\mathrm{T} 2$ relaxation times, (c) left ventricle ejection fraction and wall motion.

All of the MR examinations were performed with the same 1.5 tesla (T) MR scanner (General Electric Optima MR 360, USA). We examined the patients on supine position with a multichannel body coil and with ECG triggerring and breath-holding. The total scan time was approximately 15 minutes which included the preparation for ECG, localization and breath hold scans for the liver and the heart.

To assess the left ventricle function, a multislice cine short-axis sequence covering the whole left ventricle from base to apex was obtained with a slice thickness of $8 \mathrm{~mm}$ (TR: 4,4 msn, TE: $1.896 \mathrm{msn}$, FOV: $380 \mathrm{~mm}$, Matrix: 224x256, FA: 60, NEX: 1).

For the evaluation of cardiac iron deposition on the basis of $\mathrm{T}^{*}$ measurements, three short axis multi TE-gradient echo images at 8 different echo times were obtained at the mid-ventricular level with a slice thickness of $8 \mathrm{~mm}$ (TR: 21,9 msn, TE: 1.52-18.544 ms, FOV: 380 mm, Matrix: 224x160, FA: 20, NEX: 1).
For the evaluation of liver iron deposition, three transverse images multi-TE gradient echo images at 8 different echo times with a slice thickness of $8 \mathrm{~mm}$ were obtained at the middle of the liver, visualizing both the left and right lobes (TR: 200 msn, TE: 1.418.794 msn, FOV: 400 mm, Matrix: 160x160, FA: 20, NEX: 1$)$.

T2* measurements and left ventricular functional analysis were performed on an independent work-

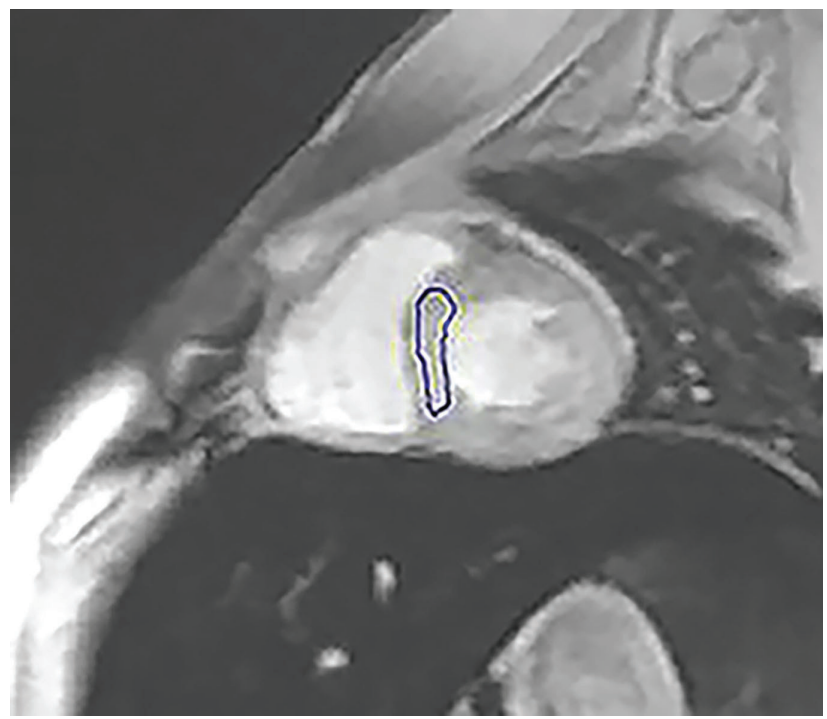

Figure 1a. T2* calculations of heart were done with multiple ROI from the interventricular septum and the median values were used.

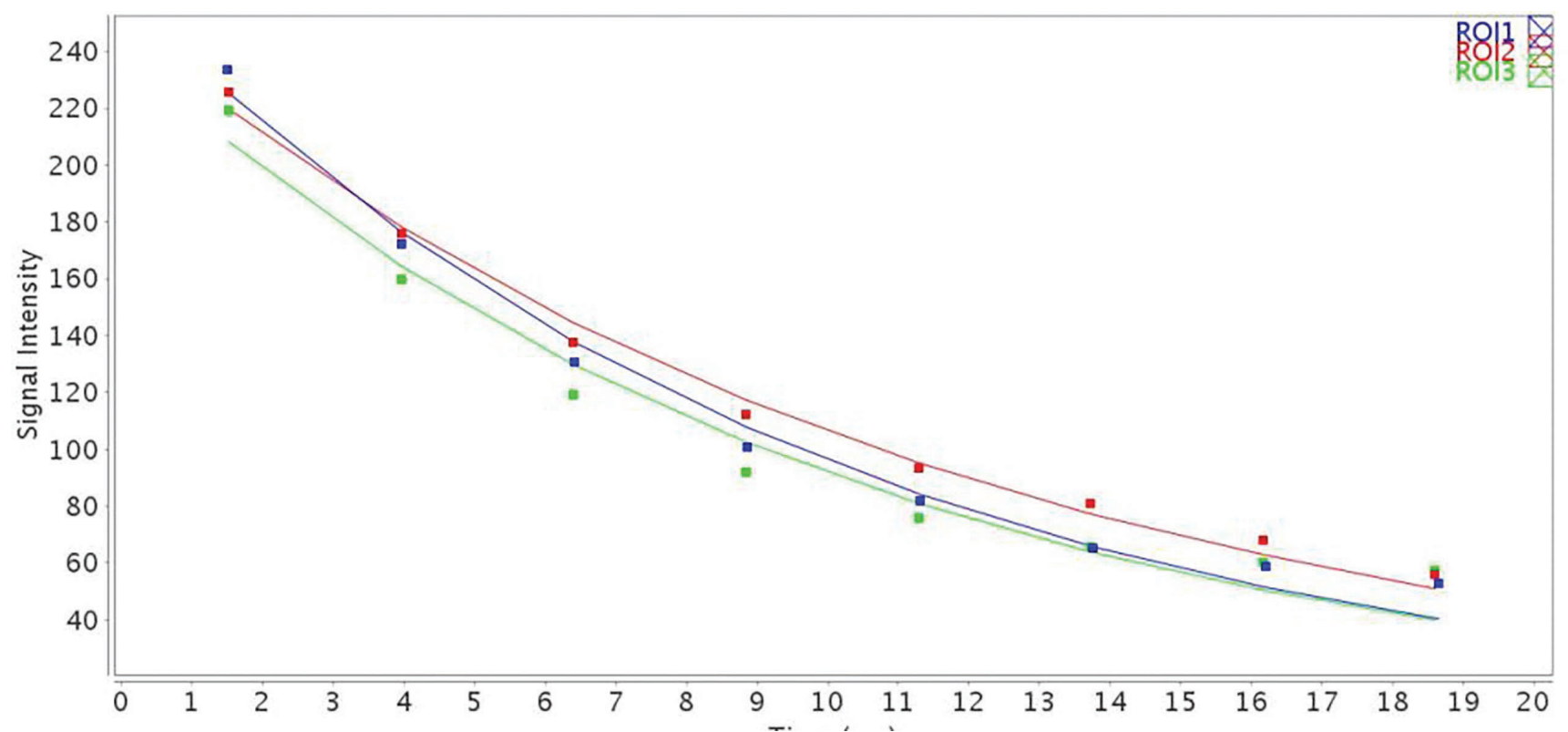

Figure $1 \mathrm{~b}$. The graph demonstrates the drop of the myocardial signal as the echo time increases. The T2* of myocardium is 9 ms and graded as moderate myocardial iron overload. 
station (Advantage Windows Volume Share 5, General Electric Healthcare) with a special software (Cardiac VX). An experienced cardiac radiologist assessed all the examinations.

For functional evaluation of the heart, cine shortaxis images were used. Calculation of the left ventricular ejection fraction and analysis of the wall motion were performed. The patients with ejection frac-

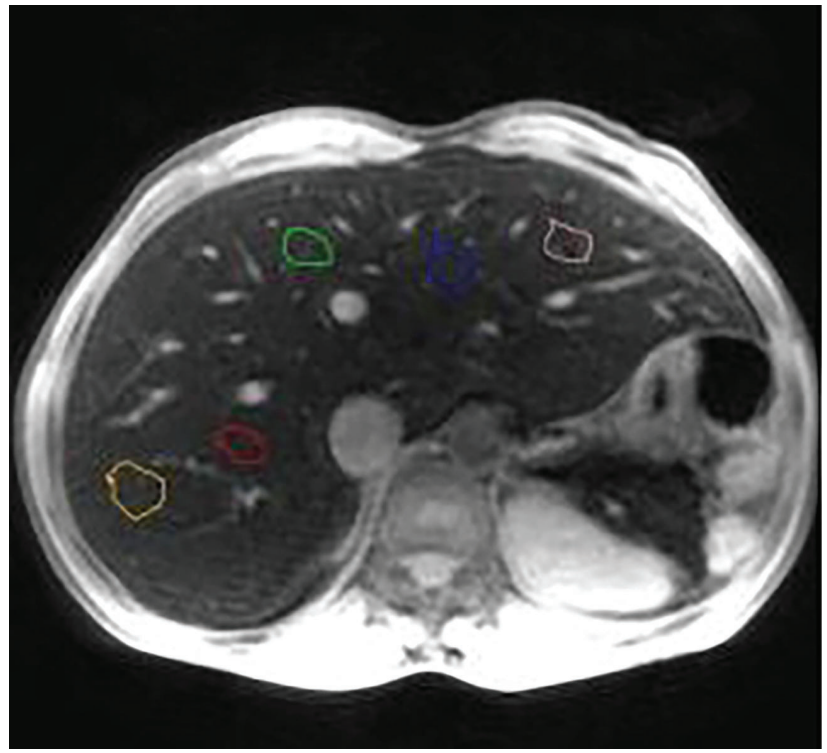

Figure 2a. For liver T2*calculations, multipl ROI were used with no segmental predeliction but avoiding vascular structures and artifacts. tion $\geq \% 55$ without wall motion abnormality were regarded to have normal cardiac functions.

For T2* calculations of heart multiple regions of interest (ROIs) from the interventricular septum and the median values were used (Figures $1 \mathrm{a}$ and $1 \mathrm{~b}$ ). Cardiac T2* values below 20 milliseconds (ms) were considered as iron overload. Iron accumulations were graded as mild (15-20ms), moderate (10-15ms) and severe (below10ms) ${ }^{(6)}$.

For hepatic T2*alculations, multiple ROIs were used with no segmental predeliction but avoiding vascular structures and artifacts (Figures $2 \mathrm{a}$ and $2 \mathrm{~b}$ ). The median values were used and $\mathrm{T} 2 *$ values below 11.4 ms were considered as iron overload. Iron accumulations were graded as mild (3.8-11.4 ms), moderate $(1.8-3.8 \mathrm{~ms})$ and severe (below1.8ms) ${ }^{(17)}$.

Serum ferritin levels between $20-250 \mathrm{ng} / \mathrm{ml}$ were accepted as normal ${ }^{(5)}$.

\section{Statistical analysis}

For the statistical analysis Statistical Package for Social Sciences (SPSS ${ }^{\circledR}$ for Windows ver. 17.0) was used. Data were presented as mean \pm standard deviation (SD).

To define the correlation between variables (cardiac iron deposition vs cardiac function, and also

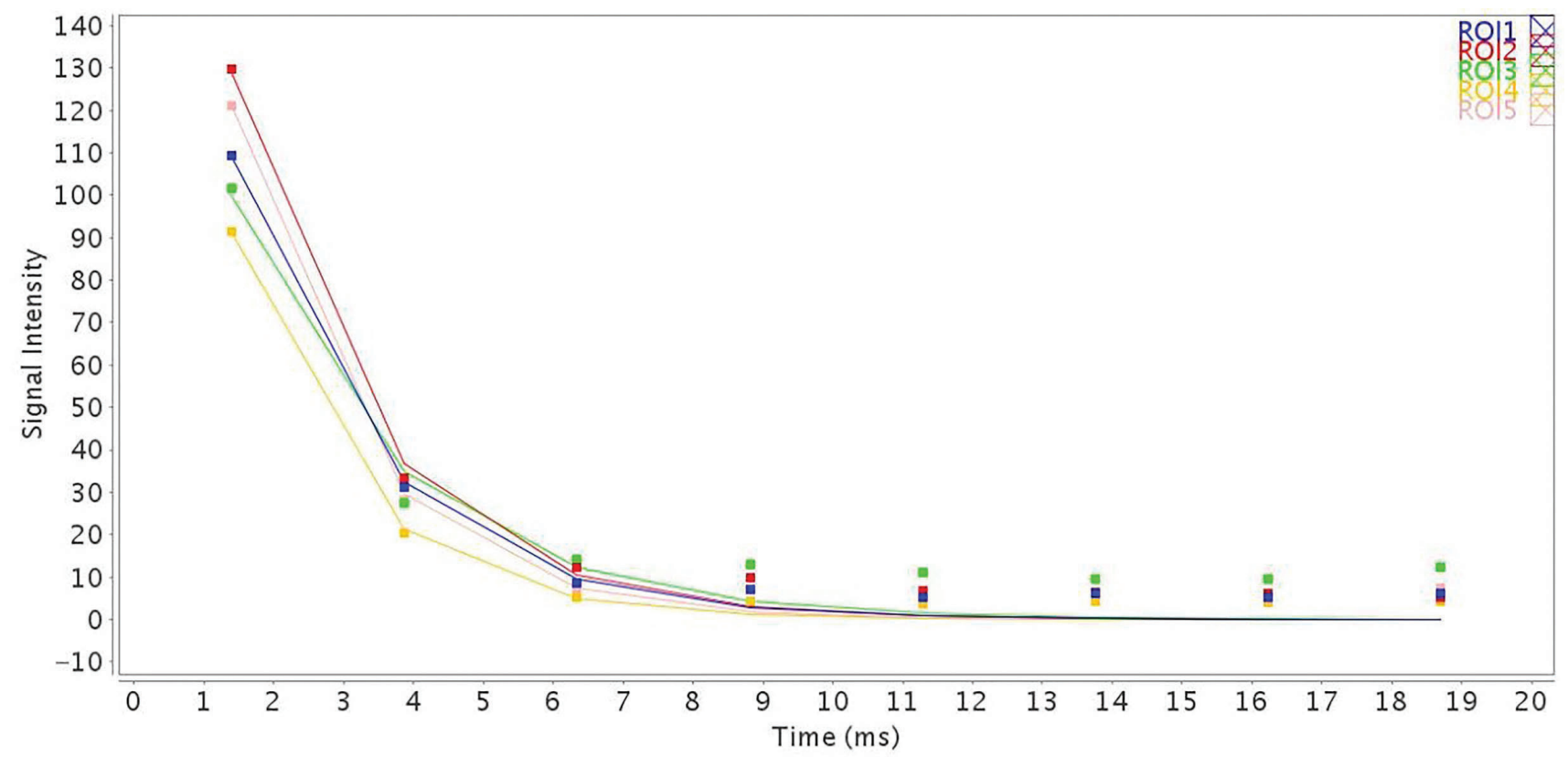

Figure $\mathbf{2 b}$. The graph demonstrates the drop of the liver parenchymal signal as the echo time increases. The T2* of liver is $2 \mathrm{~ms}$ and graded as moderate hepatic iron overload. 
D. Öncel ve ark., MR T2* Evaluation of the Hepatic and Myocardial Iron Deposition in Thalasemia Major Patients and the Correlation of the Results with Serum Ferritin Levels and Cardiac Function

myocardial, and hepatic iron vs serum ferritin levels) chi-square test was used.

Kruskal-Wallis test was used to define the significance of mean differences between the levels of myocardial and hepatic iron accumulation and serum ferritin levels. Mann-Whitney $U$ test was also used to evaluate the significance between serum ferritin levels and presence of iron accumulation.

Additionally, Receiver Operator Characteristic (ROC) curve analysis was perform to determine the cut-offs and to evaluate the significance of serum ferritin levels so as to predict the presence of iron accumulation.

$P$ value $<0.05$ was considered to be statistically significant for any given measure and the confidence interval was defined as 95 percent.

\section{RESULTS}

Our study group consisted of 145 patients including 85 males and 60 females with ages ranging between 9 to 53 years (median: 24 years). In 33 pati-

Table 1a. Age and gender distribution of patients according to myocardial iron deposition.

\begin{tabular}{lcccc}
\hline & $\begin{array}{c}\text { Cardiac } \\
\text { iron } \\
\text { Normal } \\
(>\mathbf{2 0 m s})\end{array}$ & $\begin{array}{c}\text { Cardiac } \\
\text { iron } \\
\text { Mild } \\
(\mathbf{1 5 - 2 0 m s )}\end{array}$ & $\begin{array}{c}\text { Cardiac } \\
\text { iron } \\
\text { Moderate } \\
(\mathbf{1 0 - 1 5 m s})\end{array}$ & $\begin{array}{c}\text { Cardiac } \\
\text { iron } \\
\text { Severe } \\
(<\mathbf{1 0 m s})\end{array}$ \\
\hline $\begin{array}{l}\text { Number of } \\
\text { patients }\end{array}$ & 112 & 19 & 13 & 1 \\
$\begin{array}{l}\text { Female/Male } \\
\text { Age range }\end{array}$ & $47 / 65$ & $8 / 11$ & $4 / 9$ & $0 / 1$ \\
Mean age & $9-53$ & $12-38$ & $11-33$ & 24 \\
& $24,04( \pm 7,81)$ & $24,63( \pm 6,5)$ & $23,62( \pm 6,06)$ & 24 \\
\hline
\end{tabular}

Table 1b. Age and gender distribution of patients according to hepatic iron deposition.

\begin{tabular}{|c|c|c|c|c|}
\hline & $\begin{array}{l}\text { Hepatic } \\
\text { iron } \\
\text { Normal } \\
(>11.4 \mathrm{~ms})\end{array}$ & $\begin{array}{c}\text { Hepatic } \\
\text { iron } \\
\text { Mild } \\
(3.8-11.4 \mathrm{~ms})\end{array}$ & $\begin{array}{c}\text { Hepatic } \\
\text { iron } \\
\text { Moderate } \\
(1.8-3.8 \mathrm{~ms})\end{array}$ & $\begin{array}{c}\text { Hepatic } \\
\text { iron } \\
\text { Severe } \\
(<1.8 \mathrm{~ms})\end{array}$ \\
\hline $\begin{array}{l}\text { Number of } \\
\text { patients }\end{array}$ & 31 & 50 & 46 & 18 \\
\hline Female/Male & $17 / 14$ & $22 / 28$ & $19 / 27$ & $2 / 16$ \\
\hline Age range & $10-44$ & $11-53$ & $9-34$ & $16-40$ \\
\hline Mean age & $\begin{array}{c}24,71 \\
( \pm 8,79)\end{array}$ & $\begin{array}{c}24,70 \\
( \pm 8,67)\end{array}$ & $\begin{array}{c}22,46 \\
( \pm 5,15)\end{array}$ & $\begin{array}{c}25,39 \\
( \pm 5,95)\end{array}$ \\
\hline
\end{tabular}

ents out of 145, we detected myocardial iron overload $(\mathrm{T} 2 *<20 \mathrm{~ms})$. Only one patient had severe iron deposition (T2*<10ms) whereas 19 patients had mild (T2*15-20ms) and 13 patients had moderate (T2*10-15ms) overload. Regarding liver iron, MRIs of 104 patients out of 145 revealed the presence of iron overload. Fifty patients had mild (T2* 3.8-11.4 $\mathrm{ms}), 46$ had moderate (T2* $1.8-3.8 \mathrm{~ms})$ and $18 \mathrm{had}$ severe overload The detailed demographic data including subgroups according to the extent of the liver and myocardial iron overload are given in Table 1.

Among 33 patients with cardiac iron overload, impaired myocardial function assessed by means of decreased left ventricular ejection fraction was observed in 15 patients. To assess the relationship between cardiac dysfunction and myocardial iron overload, we grouped the patients regarding the presence of myocardial iron overload (if any) and also according to the grade of iron deposition (normal, mild, moderate and severe iron overload). In both assessments, statistically significant correlation was found between cardiac dysfunction and cardiac iron accumulation ( $p>0.05, p=0.009$ and $P=0.005$, respectively).

To evaluate the correlation between cardiac and hepatic iron overload, the patients were grouped regarding the presence of iron overload (if any) and also according the grade of iron deposition (normal iron, mild, moderate and severe iron overload). In both assessments, no statistically significant correlation was detected between liver and myocardial iron overload ( $p>0.05, p=0.61$ and $\mathrm{P}=0.064$, respectively).

In all of the 145 patients in the study group, regardless of having myocardial and/or hepatic iron overload, serum ferritin levels were found to be above normal (>250 $\mathrm{ng} / \mathrm{ml}$ ).

The average serum ferritin levels were $2880 \mathrm{ng} / \mathrm{dl}$ for 33 patients with , and $1491 \mathrm{ng} / \mathrm{dl}$ for 112 patients without myocardial iron overload (Figure 3). According to Mann-Whitney $U$ test, the difference between these groups were statistically significant $(p<0.0001)$. The mean levels were also calculated for each subgroup according the grades of iron deposition and Kruskal-Wallis test revealed the significance of differences among these groups $(p=0.002)$. 
The average serum ferritin levels were $1994 \mathrm{ng} / \mathrm{dl}$ for 114 patients with, and $1119 \mathrm{ng} / \mathrm{dl}$ for 31 patients without hepatic iron overload (1366 ng/dl in mild, $2012 \mathrm{ng} / \mathrm{dl}$ in moderate and $3693 \mathrm{ng} / \mathrm{dl}$ in severe overload patients) (Figure 4). Using both MannWhitney $U$ test and Kruskal-Wallis test, the difference between these groups were found to be statistically significant ( $p<0.0001$ for both).

By using ROC analysis, a cut-off value for serum ferritin to predict myocardial iron overload was determined. The cut-off value was accepted as 1500 $\mathrm{ng} / \mathrm{ml}$ with $70 \%$ sensitivity and $66 \%$ specificity. With this new cut-off value, a statistically significant correlation was found between myocardial iron overload and serum ferritin levels, both by means of presence of iron overload and grades of severity $(p<0.001$ for both). We also determined a cut-off value for serum ferritin to predict liver iron overload with ROC analysis. The cut-off value was accepted as $850 \mathrm{ng} / \mathrm{ml}$

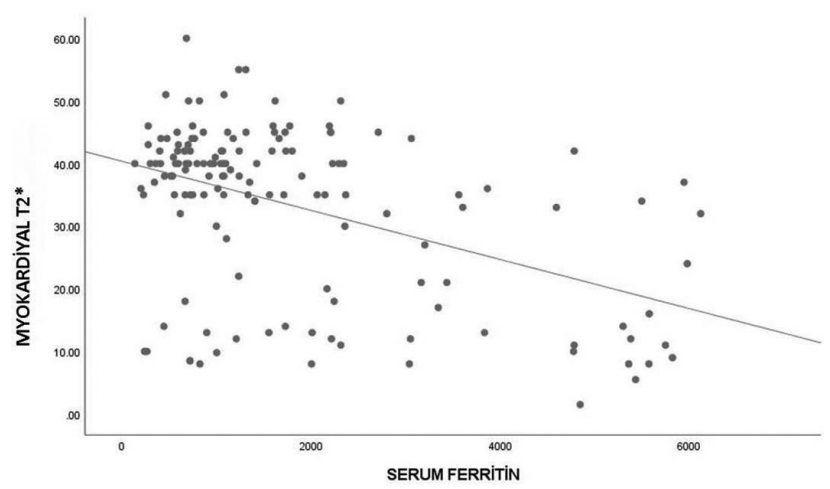

Figure 3. The correlation graphic between myocardial T2* (ms) and serum ferritin levels ( $\mathrm{ng} / \mathrm{dl})$.

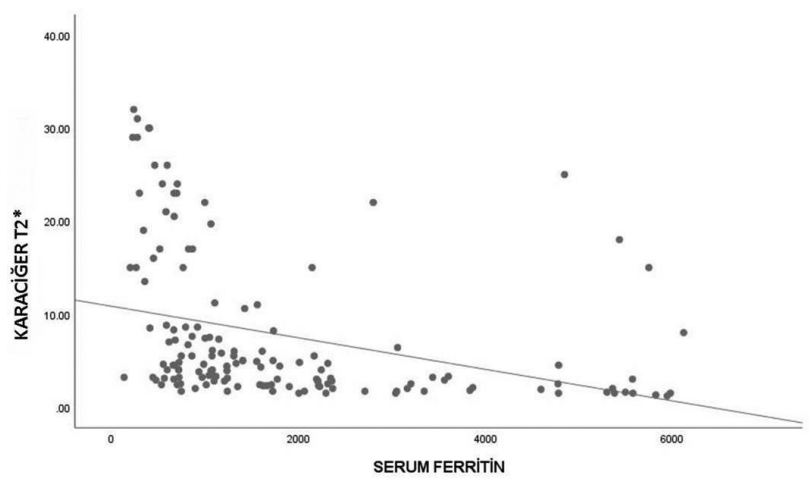

Figure 4. The correlation graphic between liver T2* (ms) and serum ferritin levels $(\mathrm{ng} / \mathrm{dl})$. with $78 \%$ sensitivity and $75 \%$ specificity. With this new cut-off value, a statistically significant correlation was found between liver iron overload and serum ferritin levels, both by means of presence of iron overload and by grades of severity ( $p<0.0001$ for both).

\section{DISCUSSION}

Thalasemia major patients receive periodical blood transfusions as is the case with conventional therapy ${ }^{(1)}$. As the human organism has no mechanism to excrete excess iron, the iron overload resulting from transfusions and also excessive iron absorption leads to accumulation of iron in the body ${ }^{(6)}$. At first, iron is accumulated in the reticuloendothelial cells of the bone marrow, spleen and liver. But at higher concentrations, iron also accumulates in parenchymal cells of the liver, heart and other organs causing toxic effects ${ }^{(6,18)}$.

Iron is usually stored in the body as crystalline iron oxide within ferritin or as hemosiderin. When the iron-binding capacity of transferrin is exceeded, free iron appears with a much higher toxicity ${ }^{(18)}$.

The liver is the dominant organ to store excessive iron. It mobilizes iron rapidly and efficiently in response to iron chelation therapy ${ }^{(17-19)}$. However, the heart has mechanisms to prevent excessive uptake and cardiac iron overload does not occur before iron binding capacity is exhausted and free iron appears in circulation ${ }^{(20)}$. Therefore myocardial iron deposition can occur much later and the heart may be spared, even though heavy iron deposition takes place in other organs. Thus, many patients can have severe liver iron overload without cardiac iron overload (20-22).

Noetzli et al. ${ }^{(23)}$ demonstrated that low hepatic iron levels or serum ferritin may not correlate with low cardiac iron deposition. As iron chelation therapy can remove iron faster from the liver than from the heart, hepatic iron may be normalized although myocardial iron is still high.

Toxic levels of cardiac iron result in cardiomyopathy and the main cause of death in the thalasemia patients is cardiac failure ${ }^{(6)}$. But cardiac functional impairment may not be detected in the early stages 
D. Öncel ve ark., MR T2* Evaluation of the Hepatic and Myocardial Iron Deposition in Thalasemia Major Patients and the Correlation of the Results with Serum Ferritin Levels and Cardiac Function

when the iron-induced cardiomyopathy is still reversible with vigorous iron chelation therapy and unfortunately, after the heart failure is established, the prognosis is usually poor ${ }^{(6-8)}$.

Currently, serum ferritin monitoring is still the most important parameter to evaluate the degree of iron overload. On the other hand, several studies in the literature did not show a significant correlation between the cardiac T2*, serum ferritin levels, and hepatic iron deposition. Therefore, serum ferritin levels and liver iron concentrations do not reliably predict the cardiac iron overload (20-25).

Because of all these, evaluation of tissue iron is fundamental for the effective monitoring of iron chelation therapy and also the clinical outcomes.

MR imaging is a well validated noninvasive method to measure both hepatic and myocardial iron levels ${ }^{(13-15)}$. Iron ions have superparamagnetic properties and cause magnetic field inhomogeneity and local magnetic field distortion ${ }^{(6,13)}$. This condition leads to shortening of the relaxation times, particularly the $\mathrm{T} 2 *$ time and results in a signal intensity loss in the affected organs in proportion to the level of iron accumulation ${ }^{(13,25,26)}$.

In our study, we found a statistically significant correlation between cardiac dysfunction and myocardial iron overload. Our results demonstrated that cardiac iron deposition may lead to functional impairment and the extent of deposition shows correlation with the impairment. This result is similar to that of several previous studies the first one being the study by Andersen et al ${ }^{(3,6,7,11,21,27)}$. T2* technique for the assessment of myocardial iron in patients with thalassemia major was firstly reported by Anderson et al. ${ }^{(6)}$. A progressive decrease in left ventricular ejection fraction was observed in parallel to the increased myocardial iron deposition and myocardial T2* was found to be less than $20 \mathrm{~ms}$ in all of the patients with ventricular dysfunction. Quatre et al. (24) on 173 patients and Leonardi et al. ${ }^{(28)}$ on 47 patients reported similar results.

In all of the patients of our study group with impaired left ventricular function $(n=15)$, there was myocardial iron overload $(\mathrm{T} 2 *<20 \mathrm{~ms})$ and none of the patients with normal myocardial $\mathrm{T} 2 *$ levels reve- aled decreased ejection fraction. But in 18 patients with high myocardial iron, cardiac function was found to be normal. This is most probably because of the fact that the deterioration of the systolic function of the heart occurs late in the course of iron toxicity. In all of these patients, vigorous iron chelation therapy may help to preserve or improve cardiac function.

In our study, we did not find a statistically significant correlation between hepatic and myocardial iron overload. This result is relevant with existing literature. Several other studies found poor or even lack of any correlation between liver and cardiac iron content including studies by Merchant et al. ${ }^{(21)}$ on 60, Barrera Portilla et al. ${ }^{(9)}$ on 16 , Wood et al. ${ }^{(20)}$ on 77 and Elfawal ${ }^{(29)}$ on 80 thalasemia patients. This is mainly due to the different iron accumulation and elimination mechanisms of the heart and the liver. Both the deposition and clearence of iron is far more rapid from the liver than from the heart. Therefore, there is substantial hepatic iron accumulation, but heart can be free of itsiron overload. Conversely, chelating treatment may cause a significant decrease in hepatic iron levels but the cardiac iron overload may still persists ${ }^{(6,20-22,26)}$.

We had 87 patients with hepatic iron overload without having excess cardiac iron deposition. This can be explained by liver being the major organ for iron deposition ${ }^{(17-19)}$. Also the heart has mechanisms to prevent iron uptake and thus iron overload is delayed compared to liver ${ }^{(20)}$. On the other hand, in 6 patients of our cohort, we detected myocardial iron overload without excessive iron in the liver. This can be explained by the liver showing more rapid clearence of iron than the heart in response to chelation therapy.

In all of the 145 patients in the study group, serum ferritin levels were above normal (>250 ng/ $\mathrm{ml}$ ). We calculated mean serum ferritin levels for patients considering the presence and extent of both myocardial and hepatic iron overload. The differences between the groups (in regard to both presence and also degrees of severity of cardiac and hepatic iron overload) as for mean serum ferritin levels were found to be statistically significant. 
These results were not correlated with current literature for myocardial iron overload. Azarkeivan et al. ${ }^{(12)}$ reported lack of any significant correlation between serum ferritin levels and myocardial T2*. Also, no correlation between serum ferritin and myocardial T2* was found in a large multicentre study by Casale et al. ${ }^{(30)}$. Our results may be due to high serum ferritin levels in all patients exceeding possible myocardial protective mechanisms. To overcome this shortcoming, we calculated a new cut-off value for serum ferritin for the prediction of myocardial iron overload (as $1500 \mathrm{ng} / \mathrm{ml}$ ) by using ROC analysis. However, several previous publications have reported that cardiac iron accumulation may occur even with low serum ferritin levels. Merchant et al. (21) stated that the serum ferritin is not a sensitive parameter to detect subclinical cardiac dysfunction and cardiac mortality can be seen in patients with low levels of serum ferritin.

The correlation between hepatic iron overload and serum ferritin levels has been also reported in several previous studies and our results are consistent with the literature ${ }^{(17,29-31)}$. However, as the levels of serum ferritin were above normal in all of our patients, we also calculated a new cut-off value for serum ferritin to predict hepatic iron overload (as $850 \mathrm{ng} / \mathrm{ml} \mathrm{ng} / \mathrm{ml}$ ).

One of the main limitations of our study is that, we did not consider the different regimens of the chelation therapy and did not evaluate the responses to the chelation therapy or monitor the changes in $\mathrm{T} 2 *$ values and cardiac function over time. Because of the retrospective nature of the study, we could not reach those details for all patients from the system. Also,we did not use another reference diagnostic tool to evaluate cardiac functions like echocardiography. Due to the retrospective nature of our study we could not reach echocardiography reports for all of the patients

High serum ferritin levels exceeding normal limits in all of our patients may also be considered as a limitation. This may be attributed to the relatively low socio-economic level of our patients with relatively poor compliance to therapy and follow up. To overcome the effect of this situation, we calculated new cut -off values for serum ferritin.

Additionally, we did not evaluate intra- and interobserver variability. However, according to previous literature, good intra- and interobserver correlations were found ${ }^{(32)}$.

\section{CONCLUSION}

As a conclusion, MR is an accurate, reproducible and noninvasive technique to detect iron overload in the heart and liver. Hepatic and cardiac iron overload can be effectively quantitated and monitored with MRI during chelation therapy. Therefore, MR not only contributes to the diagnosis of iron overload, but also have a substantial impact for the monitoring and management of thalasemia patients. Presymptomatic detection of iron deposition may allow to customize chelation therapy regimens and contribute to the prevention of organ dysfunction.

Ethics Committee Approval: Ethics Committee approval was obtained from Tepecik Training and Research Hospital (12.04.2018/3-15).

\section{Conflict of Interest: None.}

Funding: None.

Informed Consent: Obtained.

\section{REFERENCES}

1. Olivieri NF. The beta-thalasemias. N Engl J Med. 1999; 341:99-109.

https://doi.org/10.1056/NEJM199907083410207

2. Canatan D, Kose MR, Ustundag M, Haznedaroglu D, Ozbas S. Hemoglobinopathy control program in Turkey. Community Genet. 2006; 9:124- 126. https://doi.org/10.1159/000091493

3. Bayraktaroğlu S, Aydinok Y, Yildiz D, Uluer H, Savaş R, Alper $\mathrm{H}$. The relationship between the myocardial $\mathrm{T} 2 *$ value and left ventricular volumetric and functional parameters in thalassemia major patients.Diagn Interv Radiol. 2011;17(4):34651.

https://doi.org/10.4261/1305-3825.DIR.3933-10.2

4. Brittenham GM, Griffith PM, Nienhuis AW, et al. Efficacy of deferoxamine in preventing complications of iron overload in patients with thalassemia major. $N$ Engl J Med. 1994;331:567-73. https://doi.org/10.1056/NEJM199409013310902

5. Belhoul KM, Bakir ML, Saned MS, Kadhim AM, Musallam KM, Taher AT. Serum ferritin levels and endocrinopathy in medically treated patients with $\beta$ thalassemia major. Ann Hematol. 2012;91(7):1107-14.

https://doi.org/10.1007/s00277-012-1412-7 
D. Öncel ve ark., MR T2* Evaluation of the Hepatic and Myocardial Iron Deposition in Thalasemia Major Patients and the Correlation of the Results with Serum Ferritin Levels and Cardiac Function

6. Anderson LJ, Holden S, Davis B, et al. Cardiovascular T2-star $\left(\mathrm{T} 2^{*}\right)$ magnetic resonance for the early diagnosis of myocardial iron overload. Eur Heart J. 2001;22(23):2171-9. https://doi.org/10.1053/euhj.2001.2822

7. Wood JC, Tyszka JM, Ghugre N, Carson S, Nelson MD, Coates TD. Myocardial iron loading in transfusion-dependent thalassemia and sickle-cell disease. Blood. 2004;103:1934-6. https://doi.org/10.1182/blood-2003-06-1919

8. Walker JM. The heart in thalassemia major. Eur Heart J. 2002;23(2):102-5. https://doi.org/10.1053/euhj.2001.2850

9. Barrera Portillo MC, Uranga Uranga M, Sánchez González J, Alústiza Echeverría JM, Gervás Wells C, Guisasola Ínniguez A. Liver and heart T2* measurement in secondary hemochromatosis_Radiología. 2013;55(4):331-9. https://doi.org/10.1016/j.rxeng.2011.08.002

10. Vermylen $C$ et al. What is new in iron overload? Eur J Pediatr. 2008;167(4):377-81. https://doi.org/10.1007/s00431-007-0604-y

11. Tanner MA, Galanello R, Dessi C, Westwood MA, Smith GC, Nair SV, et al. Myocardial iron loading in patients with thalassemia major on deferoxamine chelation. J Cardiovasc Magn Reson. 2006;543-7. https://doi.org/10.1080/10976640600698155

12. Azarkeivan A, Hashmieh M, Akhlaghpoor S, et al. Relation between serum ferritin and liver and heart MRI T2* in beta thalassemia major patients. Eastern Mediterranean Health J. 2013;19(8):727-32. https://doi.org/10.26719/2013.19.8.727

13. Chavhan GB, Babyn PS, Thomas B, et al. Principles, techniques, and applications of T2*-based MR imaging and its special applications. Radiographics. 2009;29(5):1433-49. https://doi.org/10.1148/rg.295095034

14. St Pierre TG, Clark PR, Chua-anusorn W et al. Noninvasive measurement and imaging of liver iron concentrations using proton magnetic resonance. Blood. 2005;105:855-61. https://doi.org/10.1182/blood-2004-01-0177

15. Wood JC, et al. Impact of iron assessment by MRI. Hematology Am Soc Hematol Educ Program 2011: 443-50. https://doi.org/10.1182/asheducation-2011.1.443

16. Ghugre NR, Enriquez CM, Gonzalez I, Nelson MD Jr, Coates TD, Wood JC. MRI detects myocardial iron in the human heart. Magn Reson Med 2006; 56:681-6. https://doi.org/10.1002/mrm.20981

17. Wood JC, Enriquez C, Ghugre N, et al. MRI R2 and R2* mapping accurately estimates hepatic iron concentration in transfusion-dependent thalassemia and sickle cell disease patients. Blood. 2005;106(4):1460-5. https://doi.org/10.1182/blood-2004-10-3982

18. Hershko C, Link G, Cabantchik I. Pathophysiology of iron overload. Ann NY Acad Sci.1998;850:191-201. https://doi.org/10.1111/j.1749-6632.1998.tb10475.x

19. Angelucci E, Brittenham GM, McLaren CE, et al. Hepatic iron concentration and total body iron stores in thalassemia major. N Engl J Med. 2000;343(5):327-31. https://doi.org/10.1056/NEJM200008033430503

20. Wood JC, Origa R, Agus A, Matta G, Coates TD, Galanello R.
Onset of cardiac iron loading in pediatric patients with thalassemia major. Haematologica. 2008;93(6):917-20. https://doi.org/10.3324/haematol.12513

21. Merchant R, Joshi A, Ahmed J, Krishnan P, Jankharia B. Evaluation of cardiac iron load by cardiac magnetic resonance in thalassemia .Indian Pediatr. 2011;48(9):697-701. https://doi.org/10.1007/s13312-011-0115-9

22. Winnie C, Wing Y, Wynnie W. MRI of cardiac iron overload. J Mag Resonance Imaging. 2012;36:1052-9. https://doi.org/10.1002/jmri.23628

23. Noetzli LJ, Carson SM, Nord AS, et al. Longitudinal analysis of heart and liver iron in thalassemia major. Blood. 2008;112:2973-8. https://doi.org/10.1182/blood-2008-04-148767

24. Quatre A, Jacquier P, Petit R, Giorgi I. Thuret MRI monitoring of myocardial iron overload: Use of cardiac MRI combined with hepatic MRI in a cohort of multi-transfused patients with thalassaemia Diagnostic and Interventional Imaging. 2014;95(11):1065-9. https://doi.org/10.1016/j.diii.2014.01.007

25. Wood JC, et al. Magnetic resonance imaging measurement of iron overload. Curr Opin Hematol. 2007;14(3):183-90. https://doi.org/10.1097/MOH.0b013e3280d2b76b

26. Carpenter JP, He T, Kirk P, et al. On T2* magnetic resonance and cardiac iron. Circulation. 2011;123(14):1519-28. https://doi.org/10.1161/CIRCULATIONAHA.110.007641

27. Kirk $P$, Roughton $M$, Porter JB, et al. Cardiac T2* magnetic resonance for prediction of cardiac complications in thalassemia major. Circulation. 2009;120(20):1961-8. https://doi.org/10.1161/CIRCULATIONAHA.109.874487

28. Leonardi B, Margossian R, Colan SD, Powell AJ. Relationship of Magnetic Resonance Imaging Estimation of Myocardial Iron to Left Ventricular Systolic and Diastolic Function in Thalassemia JACC: Cardiovascular Imaging. 2008;1(5):572-8. https://doi.org/10.1016/j.jcmg.2008.04.005

29. Elfawal SK, Emara DM, Shehata AA. Assessment of hepatic and cardiac iron overload in thalassemia patients by magnetic resonance imaging: Our experience in Alexandria University .The Egyptian Journal of Radiology and Nuclear Medicine. 2018;49:323-8. https://doi.org/10.1016/j.ejrnm.2018.01.016

30. Casale M, Meloni A, Filosa A, et al. Multiparametric Cardiac Magnetic Resonance Survey in Children With Thalassemia Major A Multicenter Study. Circulation: Cardiovascular Imaging. 2015;8(8):e003230. https://doi.org/10.1161/CIRCIMAGING.115.003230

31. Hadeer S, Nivan H, Hazem M, Ahmed A, Samah S.Reassessing the value of MRI T2* in evaluation of hepatic and myocardial iron concentration: an institutional study. Egypt J Radiol Nucl Med. 2015;46:1085-90. https://doi.org/10.1016/j.ejrnm.2015.06.008

32. Kirk $\mathrm{P}, \mathrm{He} \mathrm{T}$, Anderson LJ, et al. International reproducibility of single breathhold T2* MR for cardiac and liver iron assessment among five thalassemia centers. J Magn Reson Imaging. 2010;32(2):315-9. https://doi.org/10.1002/jmri.22245 